\title{
PENYELESAIAN SENGKETA EKONOMI SYARI'AH DI PENGADILAN AGAMA KABUPATEN MALANG
}

\author{
Alifah Ratnawati \\ Kantor Kementerian Agama Kabupaten Malang \\ Email : alifahratnawati145@gmail.com
}

\begin{abstract}
Abstrak
Pengadilan Agama Kabupaten Malang termasuk dalam lingkup Pengadilan Agama Tinggi Agama Jawa Timur. Data ini menunjukan bahwa di Pengadilan Agama Kabupaten Malang telah setiap tahun selalu menerima kasus perkara ekonomi syari'ah sedangkan Pengadilan Agama lain Belum pernah menerima pengaduan tentang ekonomi syari'ah. Demikian ini memberikan gambaran permasalahan yang dapat diidentifikasikan keadaan penyelesaian sengketa ekonomi syari'ah di Pengadilan Agama Kabupaten Malang dengan mengacu pada pelaksanaan Undang-Undang Nomor 3 Tahun 2006 tentang Pengadilan Agama.
\end{abstract}

Kata kunci: ekonomi syari'ah, sengketa, kasus

\begin{abstract}
Malang Regency Religious Court is included in the scope of the High Religion Religious Court of East Java. This data shows that in the Malang District Religious Court every year they have always received cases of Shari'ah economic cases while other Religious Courts have never received complaints about the Shari'ah economy. Thus, this gives an illustration of the problems that can be identified as the state of shari'ah economic dispute resolution in the Malang District Religious Court by referring to the implementation of Law Number 3 of 2006 concerning the Religious Courts.
\end{abstract}

Keywords: syari'ah economy, dispute, case

\section{PENDAHULUAN}

Ekonomi Syari'ah telah mengalami pertumbuhan yang signifikan dalam kurun waktu dua windu terakhir. Lembaga Keuangan Syari'ah, baik yang berbentuk Perbankan maupun Non Bank tumbuh dan berkembang dengan produkproduk ekonomi syari'ahnya. Situasi seperti ini menuntun adanya regulasi yang mengatur secara khusus, terhadap jenis, produk, struktur ekonomi syari'ah, termasuk dalam penyelesaian sengketa ekonomi syari'ah. Hal ini kemudian mendorong lahirnya beberapa aturan, baik Undang-Undang, Instruksi Presiden, Peraturan Mahkamah Agung, dan lain sebagainya.

Di bidang perbankan misalnya, lahirlah UU No. 21 tahun 2008 tentang Perbankan Syari'ah, sebagai lex specialis dari model perbankan konvensional. Begitupun dalam penyelesaian sengketa ekonomi syari'ah, UU. No. 3 tahun 2006 tentang Peradilan Agama secara eksplesit menjelaskan dalam pasal 49, bahwa "Pengadilan Agama bertugas dan berwenang memeriksa, memutus, dan menyelesaikan perkara di tingkat pertama antra orang-orang yang beragama 


\section{Zurnal Negara dan $\mathcal{X}$ eadilan \\ p-ISSN 2302-7010 e-ISSN 2721-9801}

Islam di bidang a) perkawinan b) waris c) wasiat d) hibah e) wakaf f) zakat g) infaq h) shadaqah, dan i) ekonomi syari'ah

Demikian halnya sebagai rujukan penyelesaian sengketa ekonomi syari'ah diterbitkanlah Peraturan Mahkamah Agung RI No. 2 tahun 2008 tentang Kompilasi Hukum Ekonomi Syari'ah, yang memuat empat bagian, buku I tentang Subyek Hukum dan Amwal, buku II tentang Akad, buku III tentag Zakat dan Hibah, dan buku IV tentang Akuntansi Syari'ah

Dalam upaya penyelesaian sengketa di bidang ekonomi syari'ah sebenarnya juga bisa ditempuh jalur non litigasi, yaitu melalui Badan Arbitrase Syari'ah Nasional (BASYARNAS). Namun dalam tulisan ini akan dikaji terkait penyelesaian sengketa ekonomi syari'ah di Peradilan Agama.

Perkembangan sistem Ekonomi syari'ah di Indonesia saat ini semakin pesat.Kondisi ini terjadi melalui pembangunan berkelanjutan, Indonesia diharapkan mampu dan bisa bersaing di dunia, baik dari sektor perdagangan maupun perindustrian.Bermodalkan pengalaman pahit Reformasi 1998 Indonesia diharapkan mampu menjadi Negara yang lebih kuat dan unggul dalam mengatasi gejolak perekonomian yang muncul di Indonesia.

\section{METODE PENELITIAN}

Setiap riset ada metodenya. Penelitian adalah usaha secara ilmiah untuk mengetahui atau mempelajari fakta-fakta yang baru dapat diartikan sebagai penyaluran rasa ingin tahu. Penelitian pada dasarnya adalah suatu kegiatan terencana dilakukan dengan metode ilmiah bertujuan untuk mendapatkan data baru guna membuktikan kebenaran atau ketidakbenaran dari suatu gejala atau hipotesa yang ada. ${ }^{1}$ Adapun penelitian hukum merupakan suatu kegiatan ilmiah yang didasarkan pada metode, sistematika dan pemikiran tertentu yang bertujuan untuk mempelajari satu atau beberapa gejala hukum tertentu dengan jalan menganalisanya. Kecuali itu maka juga diadakan pemeriksaan mendalam terhadap fakta hukum tersebut untuk kemudian mengusahakan suatu pemecahan atas permasalahan-permasalahan yang timbul di dalam gejala-gejala yang bersangkutan. ${ }^{2}$ Penelitian ini jenisnya yuridis sosiologis dengan bahan hokum primer, skunder, dan tersier. Teknik pengumpulan bahan hukumnya dokumentasi

\section{PEMBAHASAN}

Sejalan dengan berkembangnya bidang perekonomian, di bidang perbankan juga diharapkan mampu mendongkrak pembangunan yang mulai dirintis oleh Pemerintah untuk memudahkan masyarakat bertransaksi.Berbagai banyak perbankan yang muncul di Indonesia menjadikan masalah yang muncul lebih kompleks.Tidak hanya perbankan milik Negara yang muncul, tetapi juga milik swasta, adapula perbankan berbasis Syari'ah. Bank Pembiayaan Rakyat

1. Bambang Waluyo, Penelitian Hukum Dalarn Praktek, (Jakarta: Sinar Grafika, 1991), hlm. 2

2 Soerjono Soekanto, Pengantar Penelitian Hukum, Cetakan 2, (Jakarta: Penerbit Universitas Indonesia, 1986), hlm. 21. 


\section{Hurnal Negara dan $\mathcal{X}$ eadilan \\ p-ISSN 2302-7010 e-ISSN 2721-9801}

merupakan salah satu bidang perbankan yang mulai menerapkan sistem ekonomi syari'ah.Bank Pembiayaan Rakyat Syari'ah adalah salah satu lembaga keuangan perbankan syari'ah, yang pola operasionalnya mengikuti prinsip-prinsip syari'ah ataupun muamalah syari'ah. Bank Pembiayaan Rakyat Syari'ah didirikan sebagai langkah aktif dalam restrukturisasi perekonomian Indonesia yang dituangkan dalam berbagai paket kebijaksanaan keuangan, moneter, dan perbankan secara umum, dan secara khusus mengisi peluang terhadap kebijaksanaan Bank Konvensional dalam penetapan tingkat suku bunga (rate ofinterest). Selanjutnya Bank Pembiayaan Rakyat Syari'ah secara luas dikenal sebagai sistem perbankan bagi hasil atau sistem perbankan syari'ah.

Pelaksanaan bank konvensional dalam menjalankan fungsi Bank, sebagian kalangan memandang bahwa dengan system konvensional ada hal-hal yang tidak sesuai dengan keyakinan masyarakat Indonesia yang mayoritas beragama Islam khususnya yang menolak adanya penetapan imbalan dan penetapan beban yang dikenal dengan "bunga". Praktek bunga ternyata bisa merugikan, baik bagi pihak bank sendiri maupu nasabah.

Sejak itu di Indonesia sistem perbankan Syari'ah mulai banyak dibicarakan kareana dianggap lebih tahan menghadapi krisis.Lembaga keuangan Syari'ah dianggap mampu mengatasi segala kelemahan yang terdapat dalam lembaga keuangan konvensional karena dianggap lebih arif, lebih adil, dan sesuai dengan segala kondisi masyarakat. Selain itu terdapat alasan lain yang fundamental yakni larangan agama Islam untuk memungut maupun meminjam dengan bunga serta larangan investasi untuk usaha-usaha yang dikategorikan haram. Dimana hal ini tidak dijamin oleh sistem konvensional.

Bank Pembiayaan Rakyat merupakan penjelmaan dari Bank Desa, Lumbung Desa, Bank Pasar, Bank Pegawai Lumbung Nagari, Lembaga perkreditan Desa, Badan Kredit Desa, Badan Kredit Kecamatan, Kredit Usaha Rakyat Kecil, Lembaga Perkreditan Kecamatan, Bank Karya Produksi Desa, dan atau lembaga lainnya yang dapat dipersamakan dengan itu.

Lembaga-lembaga keuangan yang disebutkan merupakan lembaga yang berpengaruh atas berdirinya Bank Pembiayaan Rakyat Syari'ah, keberadaan lembaga keuangan tersebut memunculkan pemikiran untuk mendirikan Bank Muamalat Indonesia yang berdiri pada tahun 1992, namun pada kenyatannya cakupan wilayah untuk Bank Muamalat Indonesia sangat terbatas pada wilayah tertentu seperti desa, kecamatan dan kabupaten. Maka dalam hal ini diperlukan adanya Bank Pembiayaan Rakyat untuk menangani masalah keuangan di wilayah- wilayah yang tidak dijangakau oleh Bank Muamalat Indonesia. Di Indonesia terdapat beberapa lembaga arbitrase untuk menyelesaikan berbagai sengketa bisnis yang terjadi dalam lalu lintas perdagangan, antara lain Badan Arbitrase Muamalat Indonesia yang khusus menangani masalah persengketaan dalam bisnis syari'ah, Badan Arbitrase Syari'ah Nasional yang menangani masalah-masalah yang terjadi dalam pelaksanaan Bank Syari'ah, dan Badan Arbitrase Nasional Indonesia yang khusus menyelesaikan sengketa bisnis nonIslam. Gagasan berdirinya lembaga arbitrase syari'ah di Indonesia, diawali dengan bertemunya para pakar, cendekiawan muslim, praktisi hukum, para kyai dan ulama untuk bertukar pikiran tentang perlunya lembaga arbitrase syari'ah di 


\section{Zurnal Negara dan $\mathcal{X}$ eadilan \\ p-ISSN 2302-7010 e-ISSN 2721-9801}

Indonesia. Pertemuan ini dimotori Dewan Pimpinan Majelis Ulama Indonesia pada tanggal 22 April 1992. Setelah mengadakan beberapa kali rapat dan setelah diadakan beberapa kali penyempurnaan terhadap rancangan struktur organisasi dan prosedur beracara akhirnya pada tanggal 23 Oktober 1993 telah diresmikan Badan Arbitrase Muamalat Indonesia. (Warkum 2004: 167).

Badan Arbitrase Syari'ah Nasional merupakan perubahan dari Badan arbitrase Muamalat Indonesaia yang merupakan salah satu wujud dari arbitrase syariah pertama kali didirikan di Indonesia.Pendirian Badan Arbitrase Muamalat Indonesia diprakarsai oleh Majelis Ulama Indonesia yang bertempat di Jakarta.Bentuk dari Badan Arbitrase Muamalat Indonesia berbentuk yayasan dengan akta notaris Yudo Paripurno, S.H. Nomor 175 tanggal 23 Oktober 1993

Badan Arbitrase Muamalat Indonesia sekarang telah berganti nama menjadi Badan Arbitrase Syari'ah Nasional (Basyarnas) yang diputuskan dalam Rakernas Majelis Ulama Indonesia tahun 2002. Kedudukan Basyarnas berada dibawah Majelis Ulama Indonesia dan merupakan seperangkat organisasi Majelis Ulama Indonesia sejak Rapat Kerja Nasional Majelis Ulama Indonesia tanggal 23-26 Desember 2002. Perubahan Nama tersebut dilandasi oleh sudah tidak sesuainya kedudukan Badan Arbitrase Muamalat Indonesia dengan Undang-Undang Nomor 16 Tahun 2001 tentang Yayasan.Perubahan bentuk dan pengurus Badan

Arbitrase Muamalat Indonesia dituangkan dalam Surat Keputusan Majelis Ulama Indonesia No. Kep-5 09/MUI/XII/2003 tanggal 24 Desember 2003 sebagai lembaga arbiter yang menangani penyelesaian perselisihan sengketa di bidang ekonomi syari'ah

Eksistensi Bank Syari'ah semakin kuat dengan dibentuknya peraturan pemerintah yang mengatur Perbankkan Syari'ah. Dasar hukum perbankan Syari'ah diatur dalam Undang-Undang Nomor 21 Tahun 2008 Sesuai Perbankan Nasional, Bank Pembiayaan Rakyat Syari'ah adalah perbankan yang didirikan untuk melayani Usaha Mikro dan Kecil, sektor Usaha Mikro dan Kecil ini menjadikan Bank Pembiayaan Rakyat Syari'ah berbeda dalam pasarnya dengan Bank Umum atau Bank Umum Syari'ah. Sehingga dalam sistem perbankan Syari'ah, Bank Pembiayaan Rakyat Syari'ah merupakan salah satu bentuk Bank Pembiayaan Rakyat Syari'ah yang berprinsip Syari'ah.

Undang-Undang Dasar Negara Republik Indonesia Tahun 1945 menentukan dalam Pasal 24 ayat (2) bahwa Peradilan Agama merupakan salah satu lingkungan Peradilan yang berada di bawah Mahkamah Agung bersama Badan Peradilan lainnya di lingkungan Peradilan Umum, Peradilan Tata Usaha Negara dan Peradilan Militer.

Peradilan Agama merupakan salah satu Badan Peradilan pelaku kekuasaan Kehakiman untuk menyelenggarakan penegakan hukum dan keadilan bagi rakyat pencari keadilan perkara tertentu antara orang-orang yang beragama Islam di bidang perkawinan, waris, wasiat, hibah, wakaf, zakat, infak, shodaqoh, dan Ekonomi syari'ah. Dasar hukumnya Undang-Undang Nomor 3 Tahun 2006 Perubahan Atas Undang-Undang Nomor 7 Tahun 1989 Tentang Peradilan Agama, Pasal 49 huruf i 


\section{Jurnal Negara dan Keadilan \\ p-ISSN 2302-7010 e-ISSN 2721-9801}

Dengan penegasan kewenangan Peradilan Agama tersebut dimaksudkan untuk memberikan dasar hukum kepada Pengadilan Agama dalam menyelesaikan perkara tertentu tersebut. Dalam Undang-Undang Nomor 3 Tahun 2006 Tentang Perubahan Atas Undang-Undang Nomor 7 Tahun 1989 Tentang Peradilan Agama Kewenangan Pengadilan di lingkungan Peradilan Agama diperluas, hal ini sesuai dengan perkembangan hukum dan kebutuhan hukum masyarakat, khususnya masyarakat muslim. Perluasan tersebut antara lain meliputi Ekonomi syari'ah.

Sejak tanggal 20 Maret 2006 telah ada reformasi di bidang Peradilan Agama, dimana Undang-Undang Nomor 7 Tahun 1989 Tentang Peradilan Agama diadakan perubahan dengan Undang-Undang Nomor 3 Tahun 2006. Hal yang patut disyukuri bersama adalah seiring dengan upaya pemulihan Ekonomi nasional, perkembangan industri Ekonomi berprinsip Syari'ah yang diawali dengan Perbankan Syari'ah dan Baitul MaalWattanwilatau Bank Pembiayaan Rakyat Syari'ah terbukti telah menjadi bagian dari solusi Ekonomi Nasional

Terbentuknya Pengadilan Agama Kabupaten Malang Secara Yuridis Formal didasarkan kepada peraturan perundang-undangan yang ada sejak zaman penjajah Belanda. Sampai dengan adanya amandemen Undang-Undang Dasar 1945 dan lahirnya undang-undang pada tahun-tahun berikutnya, terdiri dari: Staatsblad Tahun 1882 Nomor 152 Jo. Staatsblad Tahun 1937 Nomor 116, Undang-Undang Dasar 1945, Pasal 24 ayat (2), Undang-Undang Nomor 7 Tahun 1989 tentang Peradilan Agama Pasal 106, Undang-Undang Nomor 3 Tahun 2006 tentang Perubahan Atas Undang-undang Nomor 7 Tahun 1989 tentang Peradilan Agama.

Dasar hukum keberadaan Pengadilan Agama yang paling kuat dan mendasar adalah Undang-Undang Dasar 1945 Pasal 24 ayat (2) yang mengatakan bahwa Kekuasaan Kehakiman dilaksanakan oleh sebuah Mahkamah Agung dan Badan Peradilan yang berada dalam lingkungan Peradilan Umum, Lingkungan Peradilan Agama, Lingkungan Peradilan Militer, Lingkungan Peradilan Tata Usaha Negara dan oleh sebuah Mahkamah Konstitusi

Karena dalam Pasal 106 Undang-Undang Nomor 7 Tahun 1989 dinyatakan bahwa semua Badan Peradilan Agama yang telah ada dinyatakan sebagai Badan Peradilan Agama menurut undang-undang ini, maka Pengadilan Agama yang sudah lama ada sebelum terbitnya Undang-Undang tersebut, secara formal konstitusioanal menjadi pengadilan berdasarkan Undang-Undang dimaksud.

Pengadilan Agama Kabupaten Malang termasuk dalam lingkup Pengadilan Agama Tinggi Agama Jawa Timur. Data ini menunjukan bahwa di Pengadilan Agama Kabupaten Malang telah setiap tahun selalu menerima kasus perkara Ekonomi Syari'ah sedangkan Pengadilan Agama lain Belum pernah menerima pengaduan tentang Ekonomi Syari'ah

Hal itu memberikan gambaran permasalahan yang dapat diidentifikasikan keadaan Penyelesaian Sengketa Ekonomi Syari'ah di Pengadilan Agama Kabupaten Malang (dengan mengacu pada pelaksanaan Undang-Undang Nomor 3 Tahun 2006 tentang Pengadilan Agama Oleh Pengadilan Agama Kabupaten Malang), sebagai berikut: 


\section{Jurnal Negara dan Keadilan \\ p-ISSN 2302-7010 e-ISSN 2721-9801}

1. Perkembangan ekonomi syariah sudah berjalan sejak tahun 1992 di Indonesia, seberapa besar masyarakat melihat perkembangan ekonomi syari'ah itu

2. Keberadaan Pengadilan Agama Kabupaten Malang yang telah banyak menyelesaikan sengketa ekonomi syari'ah dibanding Pengadilan Agama yang yang lain di jawa timur

3. Kesiapan Hakim Pengadilan Agama dalam melaksanakan penyelesaian sengketa Ekonomi syari'ah yang diatur dalam Undang - Undang Nomor 3 Tahun 2006 Tentang Peradilan Agama

\section{PENUTUP}

Berbagai masalah di atas dapat dikonklusikan bahwa Pengadilan Agama Kabupaten Malang telah melaksanakan/ mengaplikasikan Undang-Undang Nomor 3 Tahun 2006 tentang tentang Pengadilan Agama dalam kaitannya dengan masalah penyelesaian sengketa ekonomi syari'ah. Penyelesaian yang dilakukan oleh Pengadilan Agama Kabupaten Malang telah didasarkan pada ketentuan peraturan perundang-undangan yang berlaku.

\section{DAFTAR PUSTAKA}

\section{Buku}

Bambang Waluyo, 1991, Penelitian Hukum Dalarn Praktek, Jakarta: Sinar Grafika.

Soerjono Soekanto, 1986, Pengantar Penelitian Hukum, Cetakan 2, Jakarta: Penerbit Universitas Indonesia.

\section{Peraturan Perundang-Undangan}

Undang-Undang Nomor 3 Tahun 2006 tentang tentang Pengadilan Agama

Undang-Undang Nomor 21 tahun 2008 tentang Perbankan Syari’ah 